\title{
Channels and gullies on the continental slope seaward of a cross-shelf trough, Labrador margin, eastern Canada
}

\author{
J. A. DOWDESWELL ${ }^{1 *}$, E. K. DOWDESWELL ${ }^{1}$, B. J. TODD ${ }^{2}$, F. SAINT-ANGE ${ }^{2}$ \& D. J. W. PIPER ${ }^{2}$ \\ ${ }^{1}$ Scott Polar Research Institute, University of Cambridge, Cambridge CB2 1ER, UK \\ ${ }^{2}$ Geological Survey of Canada, Natural Resources Canada, P.O. Box 1006, Dartmouth, Nova Scotia, CANADA,
} $B 2 Y 4 A 2$

*Corresponding author (e-mail: jd16@cam.ac.uk)

\begin{abstract}
The Labrador Shelf is characterised by several cross-shelf troughs separated by intervening shallower banks, a situation similar to that on many high-latitude continental shelves. The troughs were probably occupied by fast-flowing ice streams in the Late Pleistocene (Roger et al. 2013). Hopedale Saddle trough has a long Quaternary history of till progradation at the shelf edge, and the modern continental slope developed over a major 0.3 Ma shelf-edge failure complex (Deptuck et al. 2007). Seaward, the upper continental slope exhibits a series of relatively narrow and deep gullies, whereas the mid-slope contains wider and shallower channels that are locally anastomosing (Fig. 1a). The erosional submarine landforms on the slope are likely to be linked to the delivery of dense sediment-rich meltwater to the shelf edge from a full-glacial ice stream (Piper et al. 2012).
\end{abstract}

\section{Description}

Hopedale Saddle cross-shelf trough trends SW to NE, perpendicular to the Labrador continental shelf edge, intersecting a coast-parallel trough and forming an overall ' $\mathrm{T}$ ' shaped depression reaching $650 \mathrm{~m}$ in the main trough and locally over 900 $\mathrm{m}$ to the southeast (Fig. 1b). It is bounded to the NW and SE by the 150-200 m deep Nain and Makkovik banks, respectively (Fig. 1b). The shelf break occurs at about $350 \mathrm{~m}$ at the trough-mouth (Fig. 1a) and between $250 \mathrm{~m}$ and $300 \mathrm{~m}$ at the edge of the adjacent banks.

Multibeam-bathymetric data along a $25 \mathrm{~km}$ section of the upper continental slope seaward of the southeastern half of Hopedale Saddle show a series of gullies (Fig. 1a, d). The gullies all begin beyond the shelf edge, with the shallowest starting at 500-600 m water depth. They are relatively straight, with sinuosity indexes of $<1.05$, and reach up to $\sim 6 \mathrm{~km}$ in length. The deepest are incised just over $100 \mathrm{~m}$ and are up to $700 \mathrm{~m}$ wide, whereas the smaller gullies are a few hundred metres in width and about $20 \mathrm{~m}$ deep (Fig. 1d). Deeply incised gullies are generally symmetrical and V-shaped compared to the relatively rectangular, flat-bottomed shallow features (labelled DG and SG, respectively in Fig. 1d). In long profile, the gullies have slope angles of about $6^{\circ}$. These are comparable to the overall continental-slope gradient. The gullies terminate downslope between $1100 \mathrm{~m}$ and $1250 \mathrm{~m}$ and in some cases show depositional lobes at their termini (Fig. 1d).

On the mid-slope, a series of channels, wider and relatively flat-floored compared with the gullies (Fig. 1a), originate at about $1200 \mathrm{~m}$ depth in the southeast and $1500 \mathrm{~m}$ depth in the northwest. The channels appear morphologically unconnected to the gullies above them (Fig. 1a). Channel downslope gradients are generally between 2 and $4^{\circ}$ but up to $7^{\circ}$ for short distances of tens of metres. In planform, channels bifurcate and re-join in an anastomosing pattern (Fig. 1a). Sinuosity values range from 1.02 to 1.18. Both channel width and cross-profile become more flat-bottomed and wider downslope (Fig. 1a). Channel width is variable, with many sections between 1 and $2 \mathrm{~km}$ wide, reaching a maximum width of about $5 \mathrm{~km}$ (Fig. 1a). Channel depths reach about $200 \mathrm{~m}$.

Several high-resolution sparker seismic profiles across the upper slope show a till wedge terminating at 500-670 m, passing seaward into stratified sediment. Sleeve-gun seismic profiles suggest some till wedges reach a water depth of $850 \mathrm{~m}$. Above $640 \mathrm{~m}$ depth, the seabed is iceberg ploughed, and little post-glacial sediment has accumulated beneath the powerful Labrador Current. Age control on the stratified inter-channel sediments on the mid-slope (Fig. 1c) is provided by several well-dated piston cores. Heinrich $(\mathrm{H})$ layers rich in detrital carbonate correspond to strong reflections in sparker profiles (Saint-Ange et al. 2013). Heinrich Layer 3 (H3) is at 7-9 m beneath the seafloor, and overlies a widespread channelwidening erosional surface visible in sparker profiles. Lower slope core 60, $150 \mathrm{~m}$ above a channel floor (Piper et al. 2012), has fine sand beds below $\mathrm{H} 3$ and silt-mud laminae above, implying thick sediment-laden flows in the channels at that time. The age of deeper seismic-stratigraphic surfaces is speculative. At core MD99-2233 (Fig. 1b), H6 forms a prominent reflection, which can be correlated southward to the slope off Hopedale Saddle, where an immediately underlying erosion surface, locally overlying apparent glacigenic-debris flows, may date from a Marine Isotope Stage (MIS) 4 ice advance. Deeper glacigenic-debris flows (GDF in Fig. 1c) overlie a broad buried channel, both probably formed during MIS 6.

\section{Interpretation}

Seismic profiles, such as that from about 1,700 m on the mid-slope, suggest that the channel pattern (Fig. 1a, c) was initiated in a pre-Last Glacial Maximum (LGM) glaciation, possibly in MIS 6, and has been maintained or exhumed during later glacial advances. A mix of draping muds transported from northern glacial sources by the Labrador Current, and some overbank silts and muds from downslope flows, accumulated on the inter-channel ridges and in places at inner levees at channel margins (IL in Fig. 1a). Some of this sediment nucleated on glacigenic-debris flows that partially filled the channel system. Two channel-widening erosional events are recognised in seismic profiles, one probably in MIS 4 and one during the regional LGM shortly before H3. The anastomosing channel pattern with residual channel highs is similar to that seaward of other transverse troughs on the southeastern Canadian margin, notably on the Laurentian Fan and in Orphan Basin (Tripsanas \& Piper 2008). In the latter case, flat-floored channels are buried by prograding ice-proximal sediments. 
There is a morphological disconnect between the upper-slope gullies and the mid-slope channels (Fig. 1a). Some gullies terminate close to the crest of inter-channel ridges ( $\mathrm{X}$ in Fig. 1d). The upper slope appears to have prograded across the eroded flanks of the inter-channel ridges ( $\mathrm{Y}$ in Fig. 1d) after the pre-H3 erosional event. The prograded sediment appears stratified, but has poor seismic penetration and may comprise proximal proglacial sediment winnowed by the Labrador Current. During deposition of the youngest till wedge on the upper slope, the closely spaced gullies were probably initiated at the ice-sheet grounding line. Dense, sediment-rich meltwater discharged through the gullies may have cut the narrowtalweg channels on the margins of the wide mid-slope channels ( $\mathrm{T}$ in Fig. 1a). The distribution, spacing and dimensions of gullies are similar to those elsewhere on the eastern Canadian margin, many in areas not influenced by ice streams (Mosher et al. 2004), and to gullies on the West Antarctic margin (e.g. Noormets et al. 2009).

\section{References}

DEPTUCK, M.E., MOSHER, D.C., CAMPBELL, D.C., HUGHES CLARKE, J.E. \& NOSEWORTHY, D. 2007. Along slope variations in mass failures and relationships to major Plio-Pleistocene morphological elements, SW Labrador Sea. Submarine Mass Movements and Their Consequences, 3, 37-45.

MOSHER, D.C., PIPER, D.J.W., CAMPBELL, D.C. \& JENNER, K.A. 2004. Near-surface geology and sediment-failure geohazards of the central Scotian Slope. AAPG Bulletin, 88, 703-723.

NOORMETS, R., DOWDESWELL, J. A., LARTER, R. D., Ó COFAIGH, C. \& EVANS, J. 2009. Morphology of the upper continental slope in the Bellingshausen and Amundsen Seas: implications for sedimentary processes at the shelf edge of West Antarctica. Marine Geology, 258, 100-114.

PIPER, D.J.W., DEPTUCK, M.E., MOSHER, D.C., HUGHES CLARKE, J.E. \& MIGEON, S. 2012. Erosional and depositional features of glacial meltwater discharges on the eastern Canadian continental margin. SEPM Special Publication, 99, 61-80.

ROGER, J., SAINT-ANGE, F., LAJEUNESSE, P., DUCHESNE, M. \& ST-ONGE, G. 2013. Late Quaternary glacial history and meltwater discharges along the Northeastern Newfoundland Shelf. Canadian Journal of Earth Sciences, 50, 1178-1194.

SAINT-ANGE, F., PIPER, D.J.W., et al. 2013. Logs of piston cores, deep-water Labrador margin. Geological Survey of Canada Open File 7109.

TRIPSANAS, E.K. \& PIPER, D.J.W. 2008. Glaciogenic debris-flow deposits of Orphan Basin, offshore eastern Canada: sedimentological and rheological properties, origin, and relationship to meltwater discharge. Journal of Sedimentary Research, 78, $724-744$. 

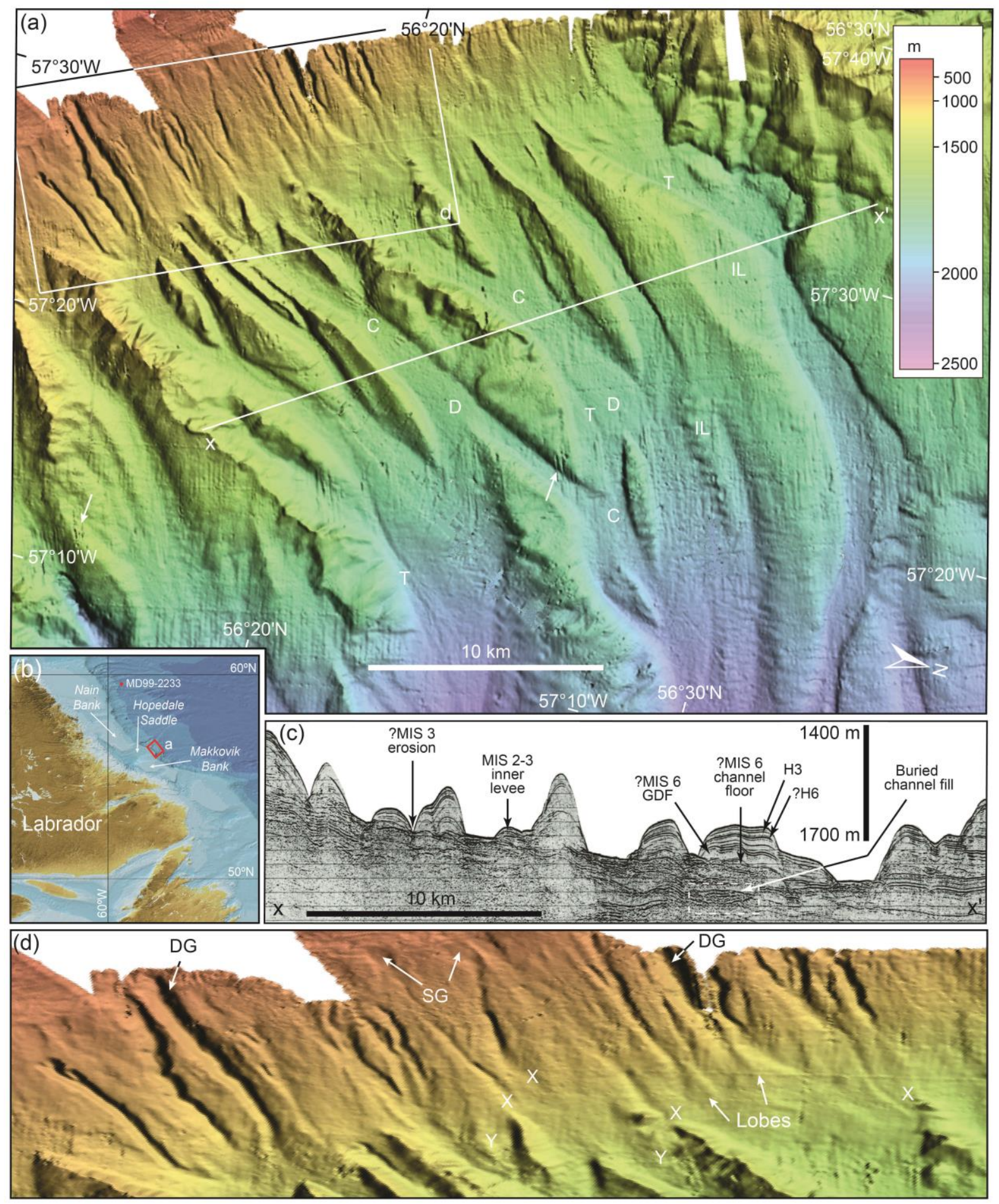

Fig. 1. Multibeam bathymetry and sub-bottom profiles of gullies and channels on the continental slope in the central Hopedale Saddle region, offshore of Labrador. (a) Swath-bathymetric image. Examples of areas of convergent (C) and divergent (D) channel sections are labelled. IL is inner levee, $\mathrm{T}$ is incised thalweg channel. White arrows indicate examples of artefacts. Acquisition system Kongsberg EM300. Frequency $30 \mathrm{kHz}$. Grid-cell size $10 \mathrm{~m}$. (b) Location of study area (red box; map from GEBCO_08). (c) Seismic-reflection profile x $-x^{\prime}$ across several of the channels along the mid-slope (located in Fig. 1a). VE x 17. Acquisition system Sleeve-gun. Frequency 120-850 Hz. MIS is Marine Isotope Stage, GFD is glacigenic-debris flow, $\mathrm{H}$ is Heinrich Layer. (d) Enlarged oblique view of the gully system (located in Fig. 1a). Image c. 18 km across. The bathymetric colour-scale and acquisition system are as Fig. 1a. Examples of both deeply incised (DG) and shallow gullies (SG) are labelled. $\mathrm{X}$ is where upper-slope gullies terminate near mid-slope inter-channel ridges. $\mathrm{Y}$ is where the upper slope appears to have prograded across inter-channel ridges. 